\title{
LIDSKÁ PRÁVA, PRÁVA DÍTĚTE, ZÁKLADNÍ ŽIVOTNÍ POTŘEBY A SOCIÁLNĚ EKOLOGICKÝ MODEL
}

Karel Hejč

MZV ČR, Praha
7: 1-200, 2005 ISSN 1212-4117
Dítětem se v souladu s článkem 1 Úmluvy OSN o právech dítěte rozumí každá lidská bytost mladší osmnácti let. Tento univerzální prvek obsažený v pojmu „každă je však narušen relativizační formulí podmiňující platnost univerzální věkové hranice aprobací právním řádem, jenž se na dítě vztahuje. ${ }^{1}$

Ačkoli se ve světových právních řádech pohybuje hranice zletilosti (a tím i formální hranice dětství) ve většině př́padů mezi 16 a 18 lety $\mathrm{s}$ jasnou inklinací k osmnáctileté věkové hranici, právní rád České republiky hranici 18 let dodržuje až na jedinou výjimku, kterou je možnost zplnoletnění pro účely sňatku, je-li to v souladu se společenským účelem manželství ${ }^{2}$, bezvýhradně, a to $\mathrm{v}$ souladu s evropským právním prostředím. Dokonce se v poslední době objevují úvahy o snížení hranice pasivního volebního práva z 21 na 18 let, nicméně se zatím nejedná o vážné a časté myšlenky, takže je nelze považovat za jakkoli určující soudobé trendy náhledu na věkovou hranici plnoletosti.

Obecná celosvětová tendence chránit zvláštními normami specifické skupiny obyvatel není nikterak nová. Od počátku padesátých let minulého století ji lze vystopovat ve smluvních či deklaratorních dokumentech zabývajících se postupně postavením otroků (1926), válečných zločinců (1949), uprchlíků (1951), žen (1952), dětí (1959), národnostních a etnických menšin (1965) a osob $\mathrm{v}$ detenčních a jiných režimových zařízeních $(1975)^{3}$. Sudre v této souvislosti tvrdí, že prijímáním analytických textů se specifickou působností je vyjádřena tendence člověka „kouskovat“ 4 . Osobně se však domnívám, že se tím mezinárodní společenství spíše než o prostou kategorizaci snaží o kvalitnější ochranu zranitelných či zranitelnějších skupin obyvatelstva a tím i o faktické naplnění existujících obecných antidiskriminačních klauzulí obsažených $\mathrm{v}$ obou základních paktech: v Mezinárodním paktu o občanských a politických právech a $\mathrm{v}$ Mezinárodním paktu o hospodářských, sociálních a kulturních právech.

Antidiskriminační klauzule obou dokumentů znějí v zásadě shodně a stanovují tak zákaz činění jakýchkoli rozdílů na základě rasy, barvy, pohlaví, náboženství, politického nebo jiného smýšlení, národnostního (etnického) nebo sociálního půvo- du, majetku, rodu nebo jiného postavení. Antidiskriminační klauzule lex specialis ochrany práv dítěte, Úmluvy o právech dítěte z roku 1989 (dále jen „Úmluva“) však jejich rozsah rozšiřuje, když mezi důvody, pro něž je diskriminace vyloučena, zařazuje ještě tělesnou nebo duševní nezpůsobilost a rod a jiné postavení nejen dítěte, ale $\mathrm{i}$ jeho rodičů nebo zákonných zástupců. Je to právě duševní nezpůsobilost, která v kombinaci se vztahem dítète $\mathrm{k}$ rodičům či zákonným zástupcům předurčuje specifické postavení dítěte v systému právní a následně i faktické ochrany. Proto je výjimečná i Úmluva: v prrípadě jiných mezinárodních smluv (a to i smluv se specifickou působnosti) zavazuje státy coby smluvní strany chránit a rozvíjet práva a svobody jednotlivců, klade jim v tomto smyslu řadu povinností a určuje jejich primární odpovědnost. Na rozdíl od nich nejsou Úmluvou vázány odpovědností primárně smluvní strany, ale rodiče dítěte a povinností státu je „toliko“ vytvářet prostředí a podmínky pro to, aby primárně odpovědný subjekt, tedy rodič, mohl své povinnosti řádně vykonávat. Tedy jinými slovy, zatímco ostatní smlouvy zavazují prímo smluvní strany, Úmluva zavazuje subjekt, který smluvní stranou vůbec není. Pravděpodobně zde podle mého názoru ustoupil právní purismus vcelku logické úvaze založené biologickou nevyvratitelností teze o unikátním vztahu rodiče a dítěte.

Kromě všech práv a svobod, které stanovují mezinárodní smlouvy všem lidem bez rozdílu (a Úmluva je pouze připomíná), jsou v Úmluvě stanoveny i některé odlišnosti, které tak jen reagují na biologickou odlišnost dospělého od dítěte. Úmluva tak zajišt'uje dítěti tato práva a svobody dospělých: právo na život, na jméno, na státní př́slušnost, svobodu projevu, právo na informace, svobodu myšlení, svědomí a náboženství, svobodu sdružovací a shromažd’ovací a právo na soukromí. Stanovuje však také práva specifická pouze ochraně dětí vycházející ze základního postulátu, vyjádřeného v článku 3 Úmluvy, totiž že „...zájem dítěte musí být předním hlediskem při jakékoli činnosti týkající se dětí،. Těmito specifiky jsou v obecné rovině:

- zákaz oddělit rodiče od svých dětí,

- úprava osvojení,

- ochrana před hospodářským a jiným vykořis- 
t’ováním a násilím,

- zásada společné odpovědnosti rodičů za výchovu a vývoj dítěte,

- právo na zvláštní ochranu (ochrana před nezákonným užíváním narkotických a psychotropních látek, před všemi formami sexuálního vykořist'ování a sexuálního zneužívání, před únosy a obchodem s dětmi, ochrana v prípadě ozbrojených konfliktů),

- zásady soudnictví pro mladistvé,

- právo na odpočinek a volný čas, na účast ve hře a oddechové činnosti.

Úmluva není unikátní jen díky své univerzálnosti (jde o dokument, $\mathrm{k}$ jehož plnění se kromě USA a Somálska zavázaly všechny státy světa), ale též díky tomu, že nemá žádnou reflexi na regionální úrovni s podobným objemem chráněných práv a měrou závaznosti.
Lze-li jen s velkými obtížemi stanovovat univerzální standardy lidských práv a základních svobod, pak stanovit univerzální obsah pojmu „základní životní potřeby“ je již zcela vyloučeno. Př́činou jsou odlišné podmínky i stav světové ekonomiky $\mathrm{v}$ jednotlivých regionech a zemích světa jakož i stav demokracie, právního státu a ochrany lidských práv $\mathrm{v}$ nich. $\mathrm{Z}$ toho lze odvodit, že zcela jinou představu o naplněných základních životních potřebách budou mít $\mathrm{v}$ zemích rozvinutých a jinou v zemích rozvojových. Pokud vyjdeme $\mathrm{z}$ předpokladu, že dětská úmrtnost je způsobena $\mathrm{v}$ podstatě nenaplněním základních životních potřeb, dává jistou průkaznost o rozdílech mezi světovými regiony diagram počtu úmrtí dětí do pěti let věku na 1.000 živě narozených $\mathrm{v}$ roce $2000^{5}$

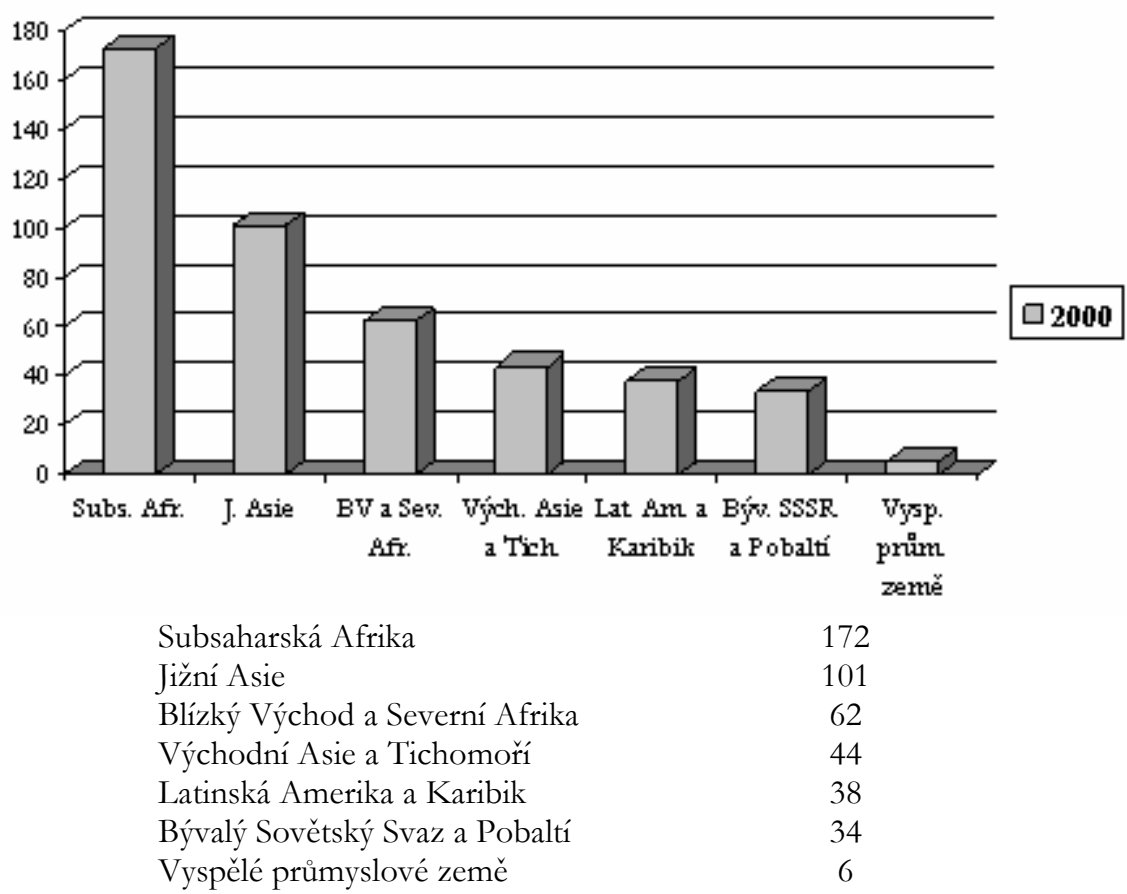

(Zdroj UNICEF, 2000)

Na tomto místě považuji za nezbytné obhájit svoji globální perspektivu, což by nemělo být nijak obtížné: Zdravotně sociální fakulta JU se možná ve svých počátcích profilovala jako regionální vysoká škola zaměřená na krytí potřeb sociální práce v regionu jižních Čech. Již dávno však díky svým zahraničním aktivitám přesáhla hranice regionu a dokonce i hranice České republiky a její studenti a absolventi nezřídka vyjíždějí za stážemi a sociální prací do zahraničí. Abychom tedy studenty ZSF připravili na skutečně globální konkurenci, je naši povinností dát jim globální perspekti- vu. Ano, asi skutečně většina $z$ nich najde své uplatnění v rámci regionu či jeho nejbližšího okolí a zřejmě ani tak nebude potřeba sociální práce zdaleka pokryta. V žádném okamžiku se však nesmíme nechat přesvědčit, že sociální potřeby našich spoluobčanů jsou ty nejfatálnější na světě. Máme-li pak v sobě minimum lidské solidarity, na níž je vlastně sociální práce postavena, měli bychom být prripraveni pomoci kdekoli na světě, budou-li ohroženy či narušeny základní životní potřeby našich spoluobčanů v nejširším smyslu.

Každý člověk může mít představu o základ- 
ních životních potřebách odlišnou. Je však zřejmé, že tato bude vždy neuspokojena a vždy prímo závislá na míře uspokojení potřeb, které jako základní nevnímáme. Odlišné budou též základní životní potřeby dospělého soběstačného jedince a základní životní potřeby dítěte a i u dítěte bude velmi záležet na věku. Obecně lze konstatovat, že za základní životní potřeby lze považovat ty, které vedou $\mathrm{k}$ uspokojení základních hodnot nezbytných pro samu lidskou existenci: život, svoboda a důstojnost. Takovými potřebami pak budou:

1. potrava (výživa),

2. zdraví (čistota, lékařská péče, voda, vzduch a životní prostředí vůbec, ochrana před infekčními a jinými nemocemi),

3. vzdělání (přístup ke vzdělání, $\mathrm{k}$ informacím, rozvoj schopností a dovedností dítěte),

4. občanská práva dítěte (ochrana rodiny, ochrana před násilím a vykořist'ováním, občanské svobody). ${ }^{6}$

Nikoli určujícím způsobem, ale motivačně pak působí možná překvapivě nikoli objektivní stav potřeb toho kterého člověka, ale naopak jeho vlastní, subjektivní vnímání naléhavosti a potrebnosti. Př́ikladem tohoto tvrzení může být velmi typická situace starých osob, kterým kolikrát daleko více než ty nejlepší léky pomůže zlepšit zdravotní stav návštěva blízké osoby, s níž si mohou chvíli povídat či které mohou vyprávět.

Správná aplikace teorie sociálně ekologického modelu je pak základním předpokladem pro další sociální aktivity směrující $\mathrm{k}$ ochraně základních životních potřeb dítěte a ke správnému návrhu asistenčních a poradenských služeb určených dítěti a jeho rodičům. Bude-li prvním faktorem určujícím kontext sociálně ekologického modelu z globálního hlediska príslušnost ke světovému regionu, nebude pravděpodobně překvapující, že základní životní potřeby dítěte $\mathrm{v}$ různých zemích světa budou jiné: zatímco dítěti v České republice bude zřejmě $\mathrm{v}$ nejvážnějším př́padě hrozit sexuální zneužívání, př́padně přemíra násilí ve sdělovacích prostředcích ${ }^{7}, \mathrm{v}$ Jihoafrické republice se asi bude jednat o problém stigmatizace dětí a rodin nakažených virem HIV, v Iráku nebezpečí poranění funkčními bojovými prostředky (nášlapné miny, nevybuchlé granáty apod.), v Bangladéši absence vhodného bydlení, pitné vody a přístupu $\mathrm{k}$ základní hygieně a lékařské péči $\mathrm{v}$ důsledku častých záplav v kombinaci se zastaralými či neexistujícími hygienickými pomůckami a slabou ekonomikou země ${ }^{8}, \mathrm{v}$ Brazílii propojení fenoménů dětské práce a dětí ulice atd.

Druhým faktorem bude př́slušnost k ekosystému: Jiné potřeby bude mít dítě žijící ve velkoměstském prostředí, jiné dítě žijící na malo- městě, jiné dítě žijící na venkově a zcela jiné dítě vyrůstající na samotě. Toto prostředí nejvíce ovlivňuje socializační schopnosti dítěte, určuje jeho přístup $\mathrm{k}$ informacím a modeluje jeho mimoškolní výchovu a vzdělávání. Nutně však zde nemusí platit, že čím intenzivnější sociální prostředí ekosystém představuje, tím lépe.

Třetím zásadním faktorem bude nejbližší sociální prostř̌edí v místě bydliště dítěte: rodina, prátele a kamarádi, školní prostředí, zájmová mimoškolní činnost, ale i sociální prostředí v místě, kde se dítě zdržuje jen občas (např. vesnice, kam dítě jezdí $\mathrm{k}$ babičce na prázdniny).

Čtvrtým faktorem je pak vlastní já každého jedince, a to i dítěte (vlastní inteligence, komunikační schopnosti, „,vnitřní svět"), které by v tomto ohledu nemělo být podceňováno či opomíjeno. ${ }^{9}$

Jak jsem uvedl v úvodu, mají jednotlivé faktory určující sociálně ekologický model prostředí, $\mathrm{v}$ němž dítě žije, rozhodující podíl na tom, jak budou dítě či jeho rodiče subjektivně vnímat jeho základní životní potřeby i na tom, jaké budou objektivně. Dovolím si však tvrdit, že - kromě naplnění základních životních funkcí - existuje jedna základní životní potřeba, která je společná všem dětem bez ohledu na to, zda vyrůstají v České republice, Jihoafrické republice, Bangladéši, Iráku či Brazílii. Myšlenka potřeby soustředění se právě na tuto potřebu je relativně nová, ne však natolik, aby svůj odraz nenalezla v Úmluvě prúijaté v roce 1989, konkrétně v článku $31^{10}$ který rúká, že ,... státy, které jsou smluvní stranou úmluvy, uznávají právo dítěte na odpočinek a volný čas, na účast ve hře a oddechové činnosti odpovídající jeho věku, jakož i na svobodnou účast $\mathrm{v}$ kulturním životě a umělecké činnosti“.

Pro kvalitní sociální práci je tedy v tomto ohledu velmi potřebné, aby byl př́slušný sociální pracovník vybaven nejen odborně, ale též psychologickým minimem a aby byl schopen prizpůsobit svoje komunikační schopnosti věku a mentální vyzrálosti dítěte, nebot' právě prostř̌ednictvím hry dítě nejlépe komunikuje. Vždyt' i odborníci ve vyspělých zemích poukazují na nedostatek rodičovské péče o duchovní rozvoj dítěte a prosté laskavosti, náklonnosti a sympatie ve vztahu $\mathrm{k}$ dítěti. ${ }^{11}$ Potřebu hry prokazuje nejen řada renomovaných institucí v čele s UNICEF ve svých studiích i praktických programech ${ }^{12}$, ale i prostý fakt, že snad jediným skutečně unifikujícím fenoménem dnešního světa je hra. U dospělých jsou to olympijské hry, v prípadě dětí pak hra jakákoli. UNICEF velmi úspěšně aplikuje hru jako relaxační a rehabilitační nástroj u dětí postižených nějakými traumaty (válka, živelná pohroma, nucená 
migrace a jevy souvisejícî. A jde-li navíc o hru, která má edukační efekt, pak je její smysl naplněn dvojnásob.

\section{Vysvětlivky k textu:}

1. Convention on the Rights of the Child. In: A Compilation of International Instruments, Volume I (First Part): United Nations. New York 1994, s. 174 a násl.. ISBN 92-1-154098-4.

2. \13 zákona č. 94/1963 Sb., o rodině, ve znění pozdějších predpisů. Sbírka zákonů ČR č. 53/1963, s. 0339.

3. List of Instruments in Chronological Order of Adoption. In: A Compilation of International Instruments, Volume I (Second Part): United Nations. New York 1993, s. 941 a násl.. ISBN 92-1-154091-7.

4. Sudre, Frédéric: Mezinárodní a evropské právo lidských práv. 1. vyd. Přel. J. Malenovský. Brno: Masarykova univerzita, 1997, s. 80. ISBN 80-210-1485-7.
5. We the children. Meeting the promises of the World Summit for Children: UNICEF. New York 2001, s. 3. ISBN 92-806-3720-7.

6. Cif. 3, ss. 19-93.

7. Concluding observations of the Committee on the Rights of the Child: The Czech Republic: United Nations. Geneva, 2003.

8. Children and war. In: Red Cross, Red Crescent. The Magazine of the International Red Cross and Red Crescent Movement: IRCRCM. Geneva 2003. ISSN 1019-9349.

9. Matoušek, Oldřich, a kol.: Metody a řízení sociální práce. Praha: Portál, 2003, s. 69. ISBN 80-7178-548-2.

10. Cif. 1, s. 186.

11. Mihál, Vladimír.: Nevytrácí se z našeho života laskavost? In: Pediatrie pro praxi 6/2003. SOLEN, Bratislava, 2003. ISSN 1213-0494.

12. Toole, M. J., Waldman, R. J.: Refugees and Displaced Persons - War, hunger and Public Health. In: Journal of American Medical Association, Vol. 270. No. 5, s. 600 - 605. Chicago, 1993.

\section{Karel Hejč \\ khejc@centrum.cz}

\section{INFORMOVANOST STUDENTU゚ LF O HOSPICOVÉ PÉČI}

\section{Jaroslav Kotrba}

Ústav sociálního lékařství LF UK v Plzni

Hospicová péče se začíná rozvijet v České republice od devadesátých let minulého století. Hospicová zařízení pomáhají nemocným i pečujícím rodinám zmírňovat jejich utrpení a neponechávají je osamocené $\mathrm{v}$ tomto těžkém období. Cílem této práce bylo zjistit informovanost studentů 5. ročníku Lékařské fakulty UK v Plzni o hospicové péči a současně i zjišt'ovat jejich názor na informovanost naší veřejnosti o poskytování této tolik potřebné hospicové péče.

\section{METODIKA}

Dotazníkové šetření bylo provedeno v celkovém souboru 165 studentů 5 . ročníku LF všeobecného směru v období let 2002-2004. Studenti odpovídali anonymně na otázky $\mathrm{v}$ předtišstěném dotazníku. Na otázky č. 1-5 bylo možno uvést současně více odpovědí, na otázky č. 6-9 byla možná jen jedna odpověd’. Odpovědi studentů byly počítačově zpracovány do přehledných tabulek, které jsou uvedeny v príloze.

\section{VÝSLEDKY}

1. Úkol paliativní léčby (tab. 1)

Všichni studenti odpověděli, že úkolem paliativní léčby je především zmírňovat utrpení nemocného. Asi polovina studentů (46,1% odpovědî) uvádí i pomoc rodině nemocného.

\section{Zařízení hospicového typu (tab. 2)}

Hospicová zařízení jsou určena pro nemocné s nevyléčitelnými onemocněními $(93,3 \%$ odpovědî), někteří studenti uváděli i možnost krátkodobých pobytů do čtyř týdnů formou respitní péče $(10,3 \%$ odpovědî).

\section{Informace o hospicové péči (tab. 3)}

Studenti získávali nejvíce znalostí o poskytování hospicové péče na přednáškách a př̀i praktic- 